\title{
Estimation and prediction of COVID-19 cases in Brazilian metropolises*
}

\author{
George Jó Bezerra Sousa ${ }^{1,2}$ \\ (D) https://orcid.org/0000-0003-0291-6613 \\ Thiago Santos Garces ${ }^{1,3}$ \\ (iD) https://orcid.org/0000-0002-1670-725X \\ Virna Ribeiro Feitosa Cestari 1,3 \\ (D) https://orcid.org/0000-0002-7955-0894 \\ Thereza Maria Magalhães Moreira ${ }^{1,4}$ \\ (iD) https://orcid.org/0000-0003-1424-0649 \\ Raquel Sampaio Florêncio ${ }^{1,3}$ \\ (D) https://orcid.org/0000-0003-3119-7187 \\ Maria Lúcia Duarte Pereira ${ }^{1,4}$ \\ (DD) https://orcid.org/0000-0003-0079-5248
}

\footnotetext{
* This article refers to the call "COVID-19 in the Global Health Context".

1 Universidade Estadual do Ceará, Fortaleza, CE, Brazil.

2 Scholarship holder at the Fundação Cearense de Apoio ao Desenvolvimento Científico e Tecnológico (FUNCAP), Brazil.

3 Scholarship holder at the Coordenação de Aperfeiçoamento de Pessoal de Nível Superior (CAPES), Brazil.

${ }^{4}$ Scholarship holder at the Conselho Nacional de Desenvolvimento Científico e Tecnológico (CNPq), Brazil.
}

Objective: to estimate the transmission rate, the epidemiological peak, and the number of deaths by the new coronavirus. Method: a mathematical and epidemiological model of susceptible, infected, and recovered cases was applied to the nine Brazilian capitals with the highest number of cases of the infection. The number of cases for the 80 days following the first case was estimated by solving the differential equations. The results were logarithmized and compared with the actual values to observe the model fit. In all scenarios, it was considered that no preventive measures had been taken. Results: the nine metropolises studied showed an upward curve of confirmed cases of COVID-19. The prediction data point to the peak of the infection between late April and early May. Fortaleza and Manaus had the highest transmission rates ( $\geq 2.0$ and $\geq 1.8$, respectively). Rio de Janeiro may have the largest number of infected people $(692,957)$ and Florianópolis the smallest $(24,750)$. Conclusion: the estimates of the transmission rate, epidemiological peak, and number of deaths from coronavirus in Brazilian metropolises presented expressive and important numbers the Brazilian Ministry of Health needs to consider. The results confirm the rapid spread of the virus and its high mortality in the country.

Descriptors: Coronavirus Infections; Social Isolation; Forecasting; Epidemiology; Epidemiologic Models; Nursing.

\section{How to cite this article}

Sousa GJB, Garces TS, Cestari VRF, Moreira TMM, Florencio RS, Pereira MLD. Estimation and prediction of COVID-19 cases in Brazilian metropolises. Rev. Latino-Am. Enfermagem. 2020;28:e3345. [Access ‘ _ _ ]; Available in: DOI: http://dx.doi.org/10.1590/1518-8345.4501.3345. 


\section{Introduction}

The new coronavirus (SARS-CoV-2) belongs to a family of viruses that cause diseases in the human respiratory system. Previous outbreaks of coronavirus (CoVs) include Severe Acute Respiratory Syndrome (SARS)-CoV and Middle East respiratory syndrome (MERS)-CoV as major threats to public health ${ }^{(1)}$.

The COVID-19 disease pandemic began in December 2019 in Wuhan, Hubei province, People's Republic of China. It quickly spread to other Chinese

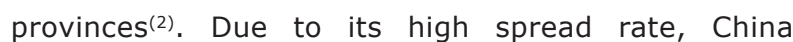
declared COVID-19 a second-class infectious disease, with management measures for a first-class infectious disease (the most dangerous category of infection)(3).

The spread of COVID-19 was rapid and global. The first confirmed case outside China was in Thailand, on January $13^{\text {th }}, 2020$. Next, cases of the disease were confirmed in Japan (January $16^{\text {th }}$ ); South Korea (January 20 ${ }^{\text {th }}$ ); Taiwan and the United States (January $21^{\text {st }}$ ); Hong Kong and Macau from China (January $22^{\text {nd }}$ ); Singapore (January $25^{\text {th }}$ ); France, Nepal, and Vietnam (January $24^{\text {th }}$ ); Malaysia and Australia (January 25 ${ }^{\text {th }}$ ); Canada (January 26 ${ }^{\text {th }}$ ); Cambodia (January $27^{\text {th }}$ ); Germany (January $28^{\text {th }}$ ); Finland, United Arab Emirates and Sri Lanka (January $\left.29^{\text {th }}\right)$; Italy, India and the Philippines (January $30^{\text {th }}$ ); United Kingdom (January $31^{\text {st }}{ }^{(4)}$, and the geographical expansion of this pandemic continues.

In this scenario, it remains to be established that the ongoing pandemic of COVID-19 is devastating, despite the extensive implementation of control measures. On January $30^{\text {th }}, 2020$, the World Health Organization (WHO) characterized the disease as a pandemic, being declared a Public Health Emergency of International Importance. As of April 1st, 2020, 823,626 cases of Covid-19 were confirmed, with 40,598 deaths worldwide(5)

In an analysis of the COVID-19 case panel in Brazil until April 1 ${ }^{\text {st }}, 6,836$ cases were confirmed by the country's Ministry of Health, in addition to 241 deaths and a fatality rate of $3.5 \%$. The cases are distributed throughout the national territory, with a greater concentration in the Southeast $(4,223$ cases; $62 \%)$, followed by the Northeast (1,007 cases; $15 \%)$, South (765 cases; 11\%), Midwest (504 cases; 7\%) and North (337 cases; 5\%)(6).

Brazilian data are alarming. In this sense, research is urgent to estimate the risk of this pandemic in Brazilian macro-regions. To know the most exposed urban centers that face the heaviest disease burden, it is imperative to closely monitor changes in epidemiology, the effect of public health strategies, and their social acceptance. Given the above, this research aimed to estimate the transmission rate, epidemiological peak, and the number of deaths by COVID-19 in the nine Brazilian capitals with the highest number of cases.

\section{Method}

The first case of COVID-19 was diagnosed on February $27^{\text {th }}, 2020$ in São Paulo. On February $3^{\text {rd }}$, a public health emergency was decreed in the country, and on March $20^{\text {th }}, 2020$, community transmission of the disease was announced in the country(7).

Thus, to understand this disease's dynamics in the population, the SIR epidemiologic model proposed by Kermack and McKendric ${ }^{(8)}$ was applied. This model rests on the idea that there are three groups of individuals: susceptible (S), infected (I), and recovered (R). The mathematical expression of the model uses three differential equations, where $\beta$ is the parameter that controls the transition between $S$ and $I$, and $Y$ is the parameter of the transition between $I$ and $R$.

In this article, the first third of Brazilian capital cities with the highest number of cases until March $27^{\text {th }}, 2020$ was investigated, which corresponds to nine capital cities (out of twenty-seven). According to the Brazilian Institute of Geography and Statistics (IBGE), the estimated Brazilian population amounts to $208,494,900$ inhabitants living in 5,571 cities, distributed in five great regions. The selected capitals were Belo Horizonte, São Paulo and Rio de Janeiro in the Southeast region; Curitiba, Florianópolis and Porto Alegre in the South; Manaus in the North; Salvador and Fortaleza in the Northeast. Brasilia, in the Midwest, would be added, but was removed from the pool of investigated cities due to difficulties to find official data.

Data were extracted from the daily epidemiological reports since the first day of confirmed cases until March 30 3020 and the capital's population was according to the IBGE ${ }^{(9)}$. Initially, graphs were created with the actual number of confirmed cases in each city until the end date, followed by their logarithmic transformation to show growth patterns. Then, the differential equations were solved for each of the nine scenarios and the number of cases was predicted until the $80^{\text {th }}$ day of infection since day one. To test the model's fit, the natural logarithm of the observed and predicted number of cases was used. They were graphically presented for the sake of a better understanding.

Moreover, the disease's basic reproduction rate $\left(R_{0}\right)$ could be identified, which shows how many 
healthy people an ill person can infect. The predicted number of cases, the day of peak, and the possible number of deaths were also investigated, considering the maximum number of people who can be sick and $1 \%$ lethality. These values were considered as if no prevention measure had been taken. Data were analyzed in R software, using the package deSolve.

This work did not require Ethics Committee approval because the state health department freely distributed the data on the internet. Yet, the authors complied with Brazilian resolution 466/2012 on ethics for research.

\section{Results}

In total, 2,829 confirmed cases of COVID-19 were analyzed in nine Brazilian capital cities. In the
Southeast, São Paulo (SP), Rio de Janeiro (RJ), and Belo Horizonte $(\mathrm{BH})$ notified the first cases on February $22^{\text {nd }}$, March $6^{\text {th }}$, and March $16^{\text {th }}$, respectively. Until the end of data collection, there were notified 1,233 cases in SP, 553 in RJ, and 163 in $\mathrm{BH}$.

Regarding the number of predicted cases, the observed cases were superior to the modeled number. In $\mathrm{BH}$, some degree of stability was observed since day 14 , with the number of cases remaining inferior to the model (Figure 1).

In the South Region, Curitiba, Florianópolis and Porto Alegre notified the first cases as from March $5^{\text {th }}$ (Porto Alegre) and March $12^{\text {th }}$ (Curitiba and Florianópolis). Until March $30^{\text {th }}$, the number of confirmed cases increased to 77 in Curitiba, 50 in Florianópolis, and 143 in Porto Alegre.
Rio de Janeiro

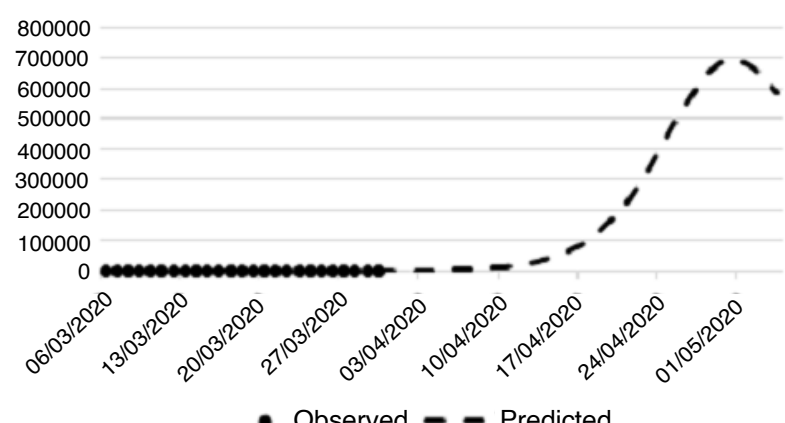

- Observed - - Predicted

São Paulo

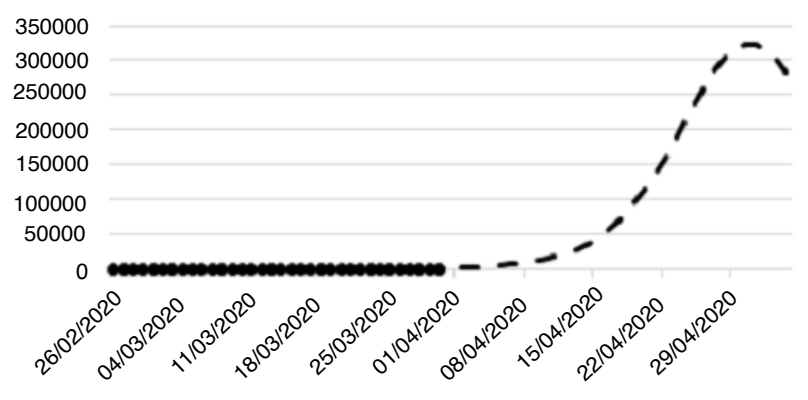

- Observed - - Predicted

Belo Horizonte

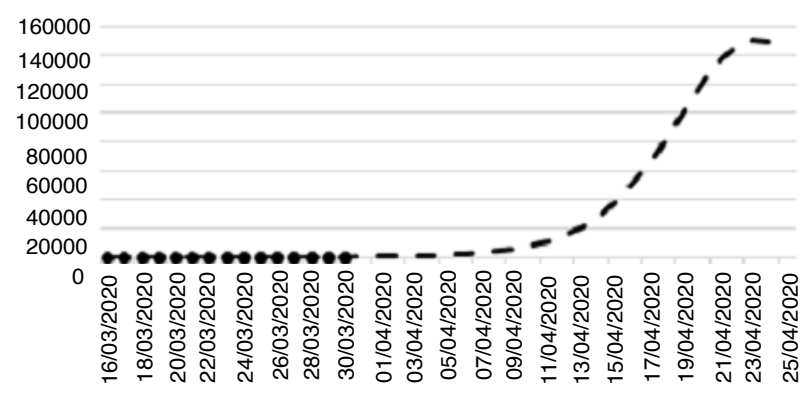

- Observed - - Predicted
Rio de Janeiro

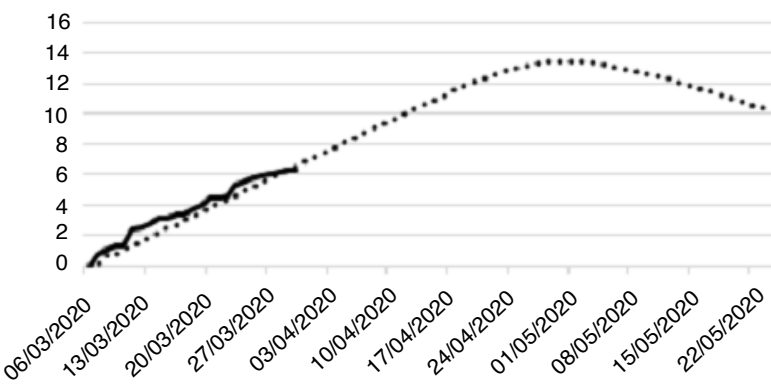

- $\mathrm{NI}^{*}$ (Observed) $\cdots . . . . \mathrm{NI}^{*}$ (Predicted)

São Paulo

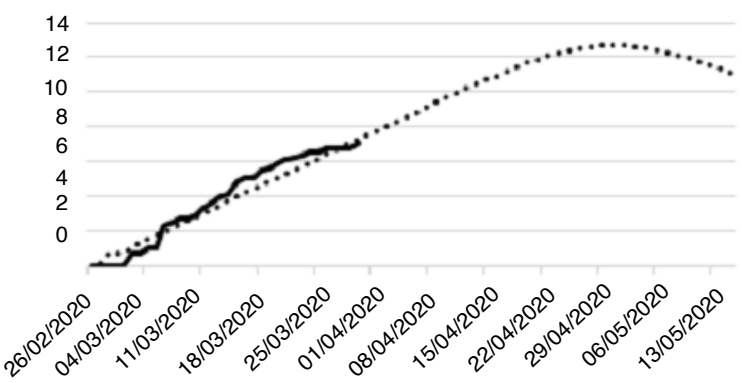

$-\mathrm{NI}^{*}($ Observed $) \cdots \cdots \cdot \mathrm{NI}^{*}$ (Predicted)

Belo Horizonte

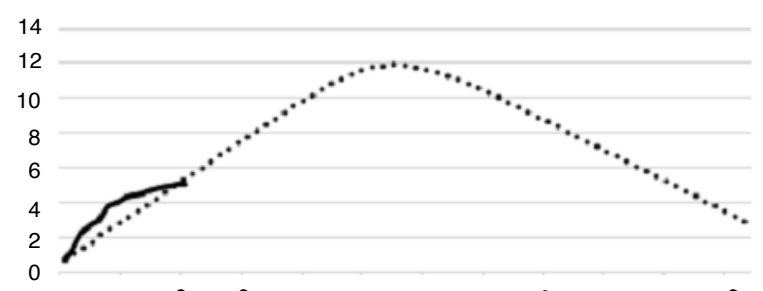

${ }^{*} \mathrm{NI}=$ Natural logarithm

Figure 1 - Projection of the number of people infected by the new coronavirus in the cities of the Southeast Region. Fortaleza, CE, 2020 
The cases estimated with the help of the SIR model in Curitiba, Florianópolis, and Porto Alegre showed that the observed and predicted case numbers were similar (Figure 2). Porto Alegre presented more observed cases than the model until the twentieth day of infection. From that point, the number of observed cases remained relatively constant and inferior to the model.

In the North Region, Manaus was the only city investigated. The first case of COVID-19 in the city was registered on March $13^{\text {th }}$ and, on the last day of the investigation, 140 cases had been registered. The sharp increase in the number of cases was similar to the model, as shown in Figure 3.

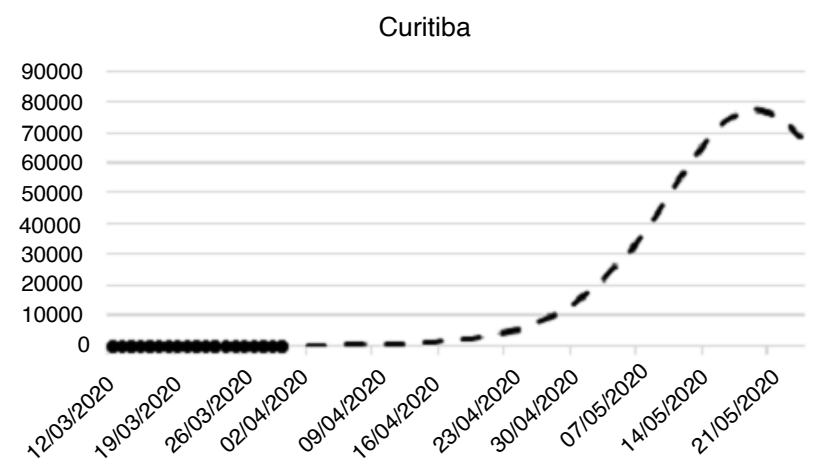

- Observed - - Predicted

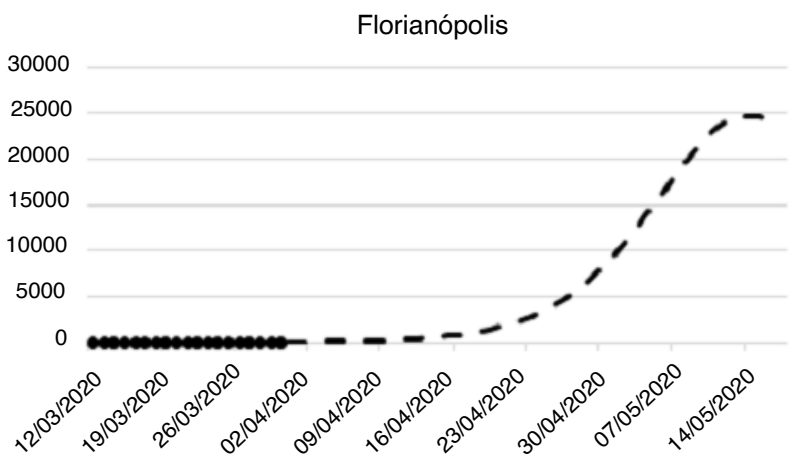

- Observed - - Predicted

Porto Alegre

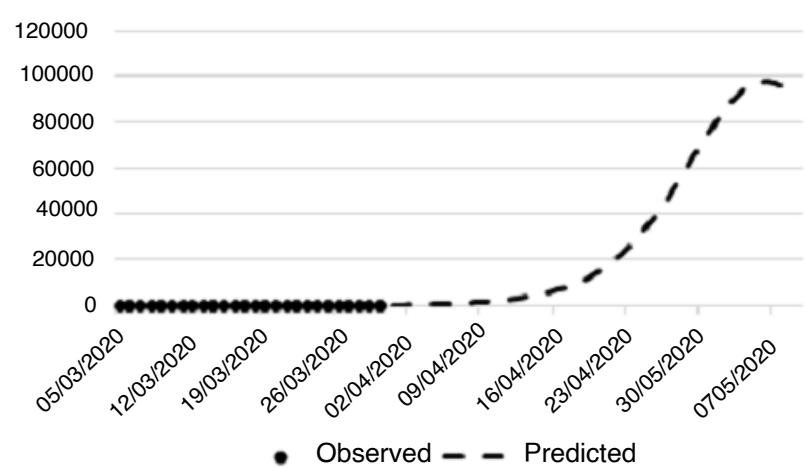

In the Northeast Region, Salvador and Fortaleza notified the first cases on March $13^{\text {th }}$ and $16^{\text {th }}$, respectively. The number of confirmed cases until March $30^{\text {th }}$ was 117 in Salvador and 382 in Fortaleza. In the predictive model, Salvador and Fortaleza presented a trend similar to the model (Figure 4).

Finally, Table 1 presents the numerical results of the outcomes predicted for COVID-19 in the capital cities under study. The prediction data appoint the occurrence of the infection peak between the end of April and the beginning of May. Fortaleza and Manaus have the highest transmission rates ( $\geq 2.0$ and $\geq 1 \cdot 8$, respectively). Rio de Janeiro may have the largest number of infected people $(692,957)$ and Florianópolis the smallest $(24,750)$.
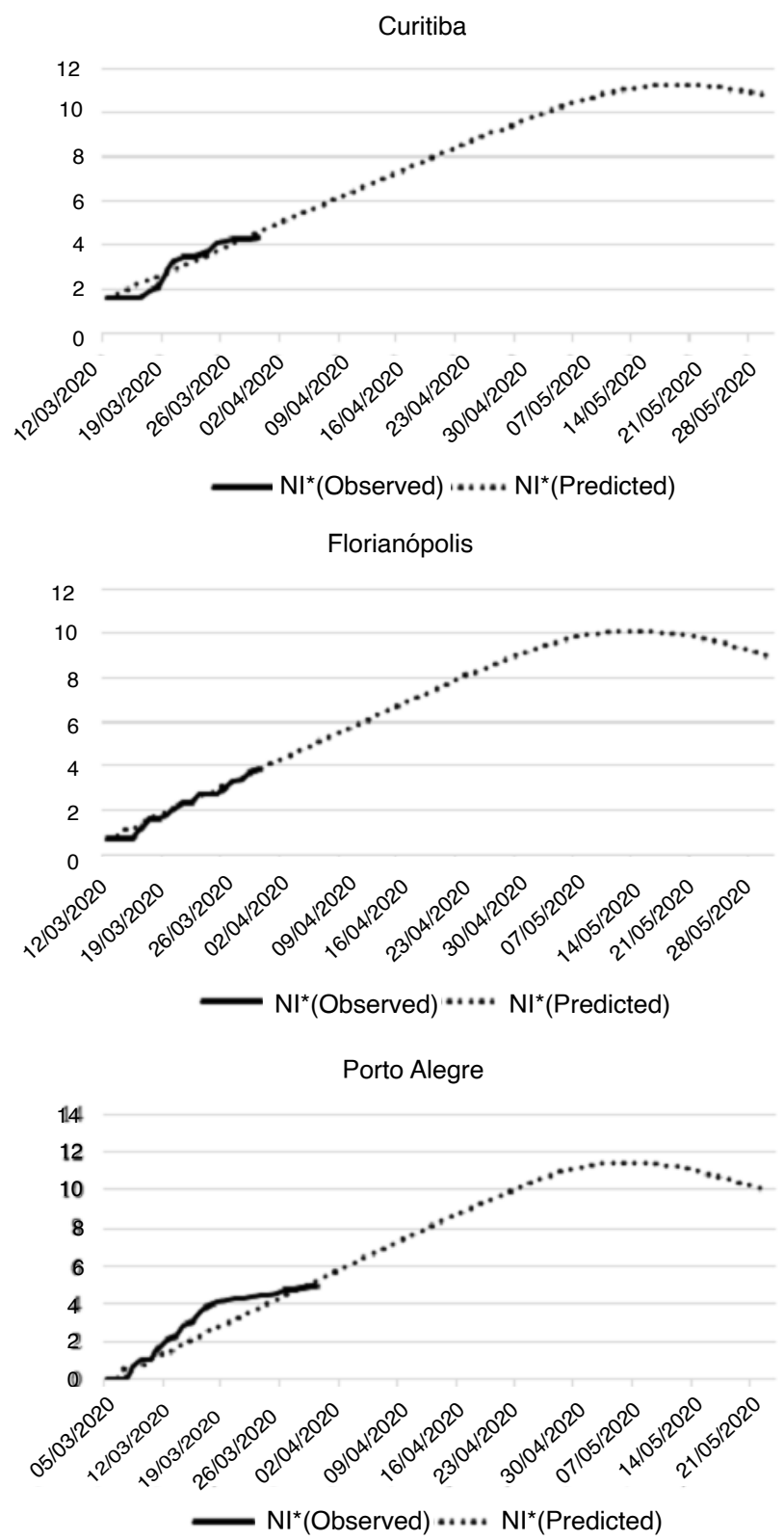

${ }^{*} \mathrm{NI}=$ Natural logarithm

Figure 2 - Projection of the number of infected people by the new coronavirus in the cities of the South Region. Fortaleza, CE, Brazil, 2020 

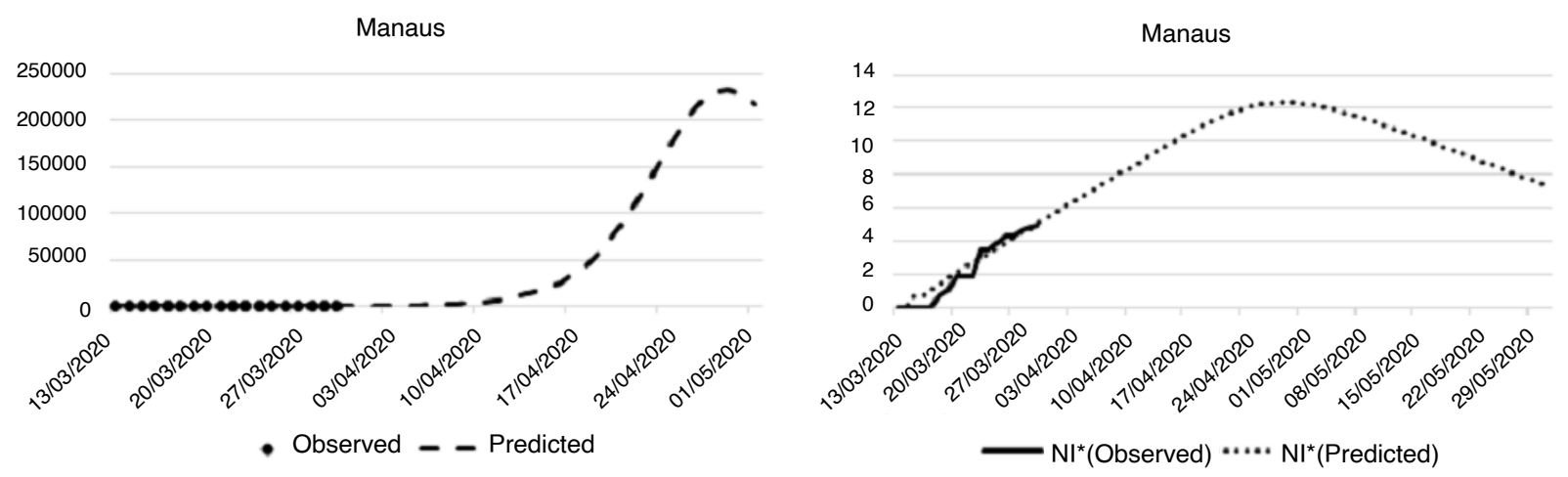

${ }^{*} \mathrm{NI}=$ Natural logarithm

Figure 3 - Projection of the number of infected people by the new coronavirus in the capital of the North Region. Fortaleza, CE, Brazil, 2020

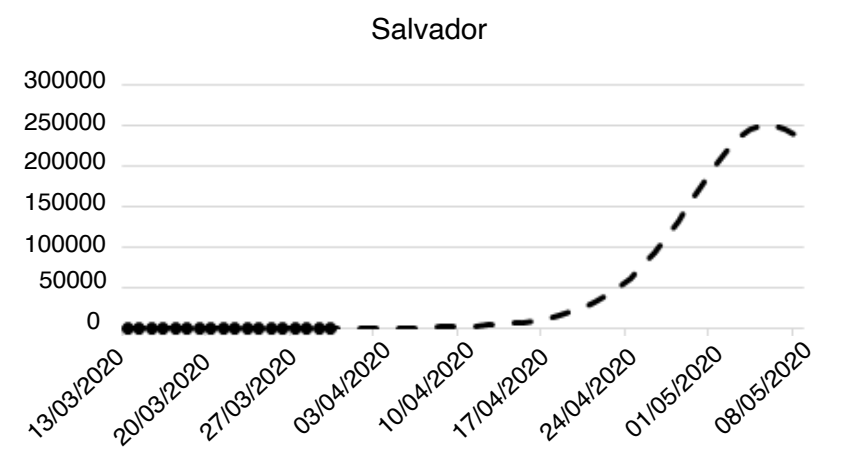

- Observed _ - Predicted

Fortaleza

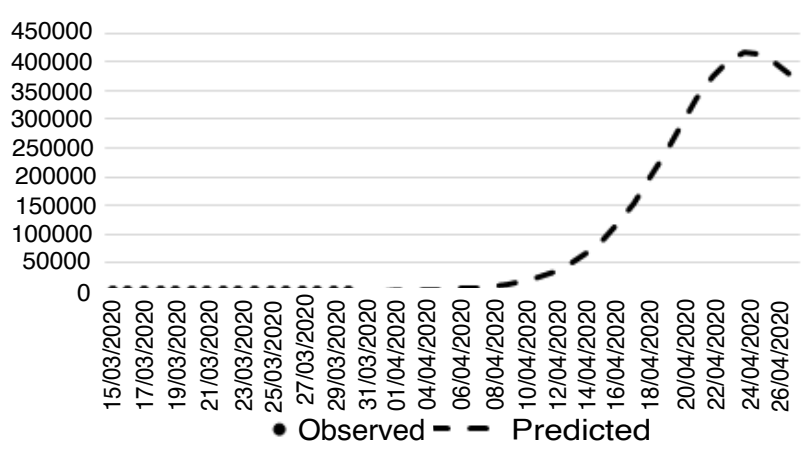

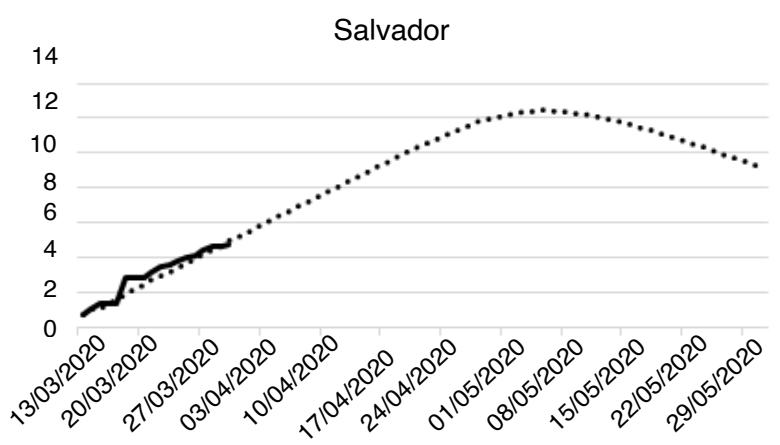

— $\mathrm{NI}^{\star}($ Observed $) \ldots \quad \mathrm{NI}^{\star}($ Predicted $)$
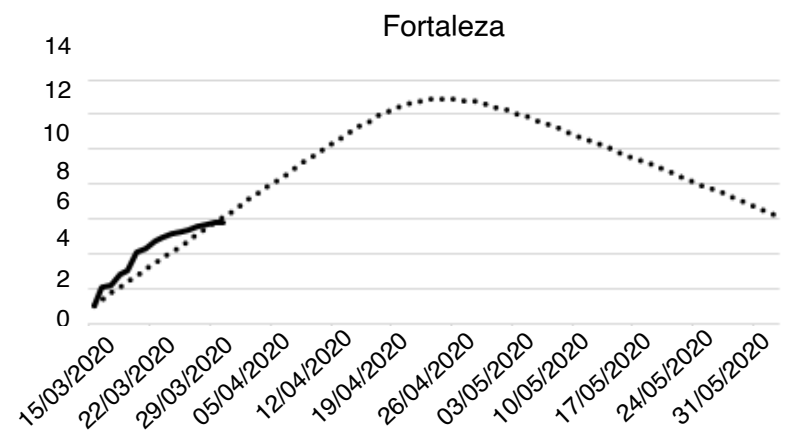

- $\mathrm{NI}^{\star}($ Observed $) \cdots \quad \mathrm{NI}($ Predicted $)$

${ }^{*} \mathrm{NI}=$ Natural logarithm

Figure 4 - Projection of the number of infected people by the new coronavirus in the cities of the Northeast Region.

Fortaleza, CE, Brazil, 2020

Table 1 - Prediction of the new coronavirus outcomes. Fortaleza, CE, Brazil, 2020

\begin{tabular}{lccccc}
\hline Capital & $\begin{array}{c}\text { Transmission } \\
\text { Rate }\end{array}$ & $\begin{array}{c}\text { Number of days from the first } \\
\text { case to the peak }\end{array}$ & Peak date & $\begin{array}{c}\text { Maximum number of } \\
\text { infected people }\end{array}$ & $\begin{array}{c}\text { Maximum } \\
\text { number of deaths }\end{array}$ \\
\hline Belo Horizonte & 1.50 & 39 & April 23 & 151,087 & 1,510 \\
Curitiba & 1.40 & 69 & May 19 & 77,303 & 773 \\
Florianópolis & 1.42 & 64 & May 14 & 24,750 & 247 \\
Fortaleza & 2.01 & 41 & April 23 & 414,946 & 4,149 \\
Manaus & 1.86 & 48 & April 29 & 231,401 & 2,314 \\
Porto Alegre & 1.53 & 63 & May 6 & 97,830 & 978 \\
Rio de Janeiro & 1.75 & 56 & April 30 & 692,957 & 6,929 \\
Salvador & 1.67 & 55 & May 06 & 249,435 & 2,494 \\
São Paulo & 1.29 & 65 & April 30 & 323,018 & 3,230 \\
\hline
\end{tabular}




\section{Discussion}

Brazil is marked by intense socioeconomic inequalities and health conditions, with relevant geographical differences, whether in the levels of health risks or the access to the resources available in the country's health system ${ }^{(10)}$. Endemics, epidemics, and pandemics have historical and social roots, and their main determinants are the poor living conditions of the population, the different forms of spatial occupation, and the lack of access to services.

Unlike other infectious diseases, COVID-19 affects developed and developing countries, making no social distinction. The results of this investigation showed the highest number of cases of COVID-19 in the Southeast region, distributed in the cities of SP and $\mathrm{RJ}$, considered the largest and most developed national metropolises and, to a lesser extent, in BH. São Paulo is the main financial, corporate, and mercantile center in South America, being the most influential Brazilian city at the global level. RJ is the largest international tourist destination in Brazil, a characteristic that led to the appearance of the first case of the disease in the country.

Also in the Southeast, BH showed an upward pattern of the disease curve. In comparison with SP and RJ, however, it presented a lower number of cases, which can be justified by having a smaller population than the two other cities, and by the more uniform distribution of basic health services and their scope. In $\mathrm{BH}$, human resources, health actions, and services offered by the Unified Health System are distributed to offer quality services, with greater equity and easy and timely access to meet the needs of a larger portion of the population (11), which can contribute to the early diagnosis and containment of disease cases.

Moving on, the South region, with the cities of Curitiba, Florianópolis and Porto Alegre, had a lower number of cases. These cities represent a major tourist, economic, and cultural center with European influence, evidenced in its predominantly elderly population. People living in cities in the South region have greater access to health services when compared to other Brazilian regions ${ }^{(12)}$.

It is worth noting that the unequal distribution of COVID-19 cases among Brazilian regions is also influenced by underreporting. The North and Northeast regions are marked by a worse assessment of the health status, greater restriction of activities, and lesser use of health services, despite the greater coverage of public programs $^{(13)}$

Representing the North region, Manaus, the state capital of Amazonas, is the main financial, corporate and commercial center of the region. It is the most populous city, with 2.1 million inhabitants and one of the largest tourist destinations in Brazil. The growth of cases in the city is expressive and linked to a social scene where asymmetry, verticality, competitiveness, and weak relations between the cities prevail, in addition to an insufficient health service network with difficulties to maintain human resources ${ }^{(14)}$.

In the Northeast region, the cases of COVID-19 were analyzed in Salvador and Fortaleza, cities with a great international travel flow. Salvador is the most populous city in the Northeast and the third in the country. Fortaleza, the state capital of Ceará, has the highest demographic density among the Brazilian capitals. In these cities, an exponential growth pattern of cases was observed and Fortaleza also presented the highest transmission rate. Currently, Fortaleza concentrates $91 \%$ of COVID-19 cases in the state of Ceará, concentrated in neighborhoods of different social and economic levels.

In this context, the number of national and international tourists who seek Brazil as a destination has increased every year. Capitals such as São Paulo, Rio de Janeiro, Curitiba, Salvador, and Fortaleza figure among the most popular destinations for tourists, whether for their natural landscapes, culture, or economic attractions. To accommodate this number of tourists, Brazil has become one of the emerging countries with the greatest potential for the development of air transport.

This is due to the country's territorial dimension and high geographical and social mobility of its population, the accelerated displacement of economic frontiers, Brazil's competitive insertion in global markets and monetary stability, and the increased purchasing power for consumers(15). The establishment of hubs in several airports has enhanced the entrance of foreigners in different countries of the world.

The economic advantages of tourism in Brazil are undeniable, however, the issues of travel and health are an existing concern. The profiles of travelers differ in terms of origin and destination, which can directly influence the occurrence of epidemics and pandemics, often of unexpected magnitude and severity ${ }^{(16)}$, such as COVID-19. Also, limited coverage and access to health services in the country can corroborate the spread of diseases.

While a small portion of the Brazilian population has access to health services, many people face a decrease in the availability of hospital beds ${ }^{(17)}$. This factor, linked to COVID-19's pandemic potential, put the response capacity of epidemiological surveillance services at the center of attention and required preventive measures from the Brazilian government, such as confinement and social distancing. 
Extensive measures are needed to reduce the interpersonal transmission of COVID-19(1). Some of the measures adopted, such as spraying disinfectant and alcohol in the air, on roads, vehicles, and people have not been effective though ${ }^{(3)}$. More expanded measures include isolation of cases, identification and monitoring of contacts, environmental disinfection, and use of personal protective equipment ${ }^{(4)}$. Regarding the control strategies, social distancing stood out as a strategy that limits human-to-human transmission, as well as reducing secondary infections between close contacts and health professionals, preventing transmission amplification events, and reducing or delaying the dissemination of the virus.

Moreover, epidemics and pandemics paralyze the economic, social, political, and cultural development, interfering in the demographic trajectory of the locations where they spread(18). The emergence of COVID-19 and its consequences has left the worldwide population with feelings of fears, concerns, and anxiety, which can further expand the disease data(19).

The biological, mental, emotional, social, and economic chaos caused by COVID-19 requires a quick response from the federal government and open and effective communication with state governors. In Brazil, divergences are observed between members of the state and federal governments as to the best measures to adopt to face this crisis. This lack of understanding is factual and may result in a greater number of deaths, as a result of the characteristics of the virus and unequal access to the health system and health technologies in the country.

The publication of the expected number of cases in the investigated metropolises in Brazilian journals is new. This evidence allows managers to organize health services, based on public policies such as the creation of hospital beds, purchasing of medical equipment, and development of health education actions to assure quarantine or social distancing.

The main limitation of this study arises from the use of a secondary database, as data for some cases were incomplete. Furthermore, underreporting and/or insufficient testing might influence the predicted peak. It is also important to highlight that the results did not consider social distancing measures that aim to reduce the transmission rate of the virus.

\section{Conclusion}

The estimates of the transmission rate, epidemiological peak, and number of deaths by COVID-19 in the Brazilian metropolises presented expressive and important numbers which the Brazilian Ministry of Health should take into account. All metropolises showed an exponential growth in the number of cases. The transmission rate was higher in Fortaleza and in Manaus, where many deaths are expected. Thus, the results confirm the rapid spread of the virus and its high mortality in Brazil.

\section{Acknowledgments}

We would like to thank all epidemiological surveillance professionals in the Brazilian states.

\section{References}

1. Rothan HA, Byrareddy SN. The epidemiology and pathogenesis of coronavirus disease (COVID-2019) outbreak. J Autoimmun. [Internet]. 2020 [cited Apr 20, 2020]; 102433. doi: https://doi.org/10.1016/j. jaut.2020.102433

2. Ji W, Wang W, Zhao X, Zai J, Li X. Cross species transmission of the newly identified coronavirus 2019nCoV. J Med Virol. [Internet]. 2020 [cited Apr 20, 2020]; 92:433-40. doi: https://doi.org/10.1002/jmv.25682

3. Xiao $Y$, Torok ME. Taking the right measures to control COVID-19. Lancet Infec Dis. [Internet]. 2020 [cited Apr 20, 2020]. doi: https://doi.org/10.1016/S14733099(20)30152-3

4. Adhikari SP, Mend S, Wu YJ, Mao YP, Ye RX, Wand QZ, et al. Epidemiology, causes, clinical manifestation and diagnosis, prevention and control of coronavirus disease (COVID-19) during the early outbreak period: a scoping review. Infect Diseases Poverty. [Internet]. 2020 [cited Apr 20, 2020];29. doi: https://doi.org/10.1186/s40249020-00646-x

5. Organização Pan-Americana da Saúde. Organização Mundial da Saúde. Folha informativa - COVID-19 (doença causada pelo novo coronavírus). [Internet]. 2020 [Acesso 20 abr 2020]. Disponível em: https:// www.paho.org/bra/index.php?option=com_content\&vie $\mathrm{w}=$ article\&id $=6101:$ covid19\&Itemid $=875$

6. Ministério da Saúde (BR). Painel de casos de doença pelo coronavírus 2019 (COVID19) no Brasil pelo Ministério da Saúde. [Internet]. 2020 [Acesso 20 abr 2020]. Disponível em: https://covid.saude.gov.br/

7. Diário Oficial da União (BR). Portaria no 454, de 20 de março de 2020. Declara, em todo o território nacional, o estado de transmissão comunitária do coronavírus (covid-19). Diário Oficial da União. 20 mar 2020 [Acesso 20 abr 2020]. Disponível em: http://www.in.gov. br/en/web/dou/-/portaria-n-454-de-20-de-marcode-2020-249091587

8. Kermack WO, McKendrick AG. Contributions to the mathematical theory of epidemics. P Roy Soc A-Math 
Phy. 1927;772:700-21. doi: https://doi.org/10.1098/ rspa.1927.0118

9. Instituto Brasileiro de Geografia (BR). Cidades IBGE. Brasília: IBGE; 2020 [Acesso 20 abr 2020]. Disponível em: https://cidades.ibge.gov.br/

10. Barreto ML. Health inequalities: a global perspective. Cienc Saude Colet. [Internet]. 2017 [cited Apr 20, 2020]; 22(7). doi: https://doi.org/10.1590/141381232017227.02742017

11. Souza RCF, Oliveira VB, Pereira DB, Costa HSM, Caiaffa WT. Living near health at Belo Horizonte. Cad Metrop. [Internet]. 2016 [cited Apr 20, 2020];18(36):325-44. doi: https://doi.org/10.1590/2236-9996.2016-3601

12. Stopa SR, Malta DC, Monteiro CN, Szwarcwald CL, Goldbaum M, Cesar CLG. Use of and access to health services in Brazil, 2013 National Health Survey. Rev Saude Publica [Internet]. 2017 [cited Apr 20, 2020];51(1):3. doi: https://doi.org/10.1590/s15188787.2017051000074

13. Viacava F, Bellido JG. Health, access to services and sources of payment, according to household surveys. Cienc Saude Coletiva. [Internet]. 2016 [cited Apr 20, 2020];21(2):351-70. doi: https://doi. org/10.1590/1413-81232015212.19422015

14. Gamelo L, Sousa ABL, Silva CO. Health regionalization in Amazonas: progress and challenges. Cienc Saude Coletiva. [Internet]. 2017 [cited Apr 20, 2020];22(4). doi: https://doi.org/10.1590/141381232017224.27082016

15. Pereira APC. Who are they? Where do they go? the regional airline sector in Brazil. Confins. [Internet]. 2016 [cited Apr 20, 2020];29. doi: https://doi.org/10.4000/ confins. 11419

16. Teixeira MG, Costa MNC, Paixão ES, Carmo EH, Barreto FR, Penna GO. The achievements of the SUS in tackling the communicable diseases. Cienc. Saude Colet [Internet]. 2018 [cited Apr 20, 2020];23(6). doi: https://doi.org/10.1590/1413-81232018236.08402018 17. Albuquerque MV, Viana ALA, Lima LD, Ferreira MP, Fusaro ER, Iozzi FL. Regional health inequalities: changes observed in Brazil from 2000-2016. Cienc Saude Coletiva. [Internet]. 2017 [cited Apr 20, 2020];22(4):1055-64. doi: https://doi. org/10.1590/1413-81232017224.26862016
18. Bassanezi MSB, Cunha MF. One place, two epidemic moments: yellow fever (1896-1897) and influenza (1918-1919) outbreaks in Campinas, Sao Paulo. Rev Bras Est Pop. [Internet]. 2019 [cited Apr 20, 2020];36:1-29. doi: https://doi.org/10.20947/s0102-3098a0088

19. Ahorsu DK, Lin CY, Imani V, Saffari M, Griffiths MD, Pakpour AH. The fear of COVID-19 Scale: development and initial validation. Int $\mathrm{J}$ Mental Health Addict. [Internet]. 2020 [cited Apr 20, 2020]. doi: https://doi. org/10.1007/s11469-020-00270-8
Received: Apr 23rd, 2020 Accepted: May $6^{\text {th }}, 2020$

Associate Editor: Evelin Capellari Cárnio

Copyright $\odot \mathbf{2 0 2 0}$ Revista Latino-Americana de Enfermagem This is an Open Access article distributed under the terms of the Creative Commons (CC BY).

This license lets others distribute, remix, tweak, and build upon your work, even commercially, as long as they credit you for the original creation. This is the most accommodating of licenses offered. Recommended for maximum dissemination and use of licensed materials. 